\title{
Can Online Tutors Improve the Quality of E-Learning?
}

\section{Viktorija Sulčič and Alja Sulčič UP Faculty of Management, Koper, Slovenia}

\section{viktorija.sulcic@fm-kp.si alja.sulcic@gmail.com}

\begin{abstract}
In the paper we tried to present online tutoring as a solution to quality issues of e-learning that elearning providers from all over the world are facing. We also briefly presented different roles of online tutors and the skills needed to perform these roles successfully. The online tutoring system was introduced to support students of e-learning courses at our faculty. Through various researches we tried to ascertain the impact online tutors have on student activity and study success. Our researches showed that tutors can improve study outcomes (although not so much students' grades) and that their activity is well accepted by students (especially part-time students). Finally, we tried to combine all of our findings in a model for online tutoring that tries to identify the key elements and skills tutors need for an efficient support of e-learning delivery.
\end{abstract}

Keywords: e-learning, online tutors, tutorial learning, higher education, blended learning.

\section{Introduction}

E-learning is a form of learning in which the educational process is supported by information and communication technology (ICT). ICT was first used to support the delivery process in distance education (DE) to overcome the spatial and time separation between the teacher and students. The specifics of distance education stimulated the development of appropriate teaching and learning methods for over 100 years (Holmeberg 1995) of DE history. The DE methods stimulated active student participation and improved study outcomes. With the gradual introduction of ICT in traditional education, the DE teaching/learning methods were transferred to traditional education because of their innovative approach to teaching and learning. In this context new forms of learning emerged, varying from computer based learning, online learning, web-based learning, e-learning etc. All these new forms of learning that use ICT can therefore be called e-learning.

E-learning has became a popular form of learning in USA's enterprises, where the share of elearning suppliers showed significant growth in the last years in respect to the share of suppliers of other forms of learning (Mugania, 2004, p. 1). The e-learning enthusiasm is similar to the enthusiasm of the dot.com boom, during which the great expectations of enterprises involved in e-

Material published as part of this publication, either on-line or in print, is copyrighted by the Informing Science Institute. Permission to make digital or paper copy of part or all of these works for personal or classroom use is granted without fee provided that the copies are not made or distributed for profit or commercial advantage AND that copies 1) bear this notice in full and 2) give the full citation on the first page. It is permissible to abstract these works so long as credit is given. To copy in all other cases or to republish or to post on a server or to redistribute to lists requires specific permission and payment of a fee. Contact Publisher@InformingScience.org to request redistribution permission. business failed to materialize. A Britain's e-university's (UKeU) case (MacLeod, 2004) showed that the ICT is not the only factor for successful elearning. Although the UKeU used the latest technology and prepared high quality study materials, only 900 students compared with the target 5,000 signed up at UKeU (MacLeod, 2004). As many e-learning researches showed, other institutions were also facing the 
problem of high drop-out rates. We summarized some of these findings in Table 1, and although different authors reported different figures, the data is alarming.

Table 1: An estimation of drop-out rates in online courses

\begin{tabular}{cl}
\hline Drop-out rates & The author and year of the research's publication \\
\hline $70-80 \%$ & Forester 2000 (in Dagger and Wade 2004), Flood 2002 \\
Over 70\% & Mugania 2004; Masie Center (2003) \\
Over $40 \%$ & Carter 1996 (in Tyler-Smith 2006) \\
$20-50 \%$ & Ridley and Sammour 1996 (in Diaz 2002), Frankola 2001 (in Masie Cen- \\
$10-20 \%$ & ter 2003) \\
\hline
\end{tabular}

As seen in Table 1, there is a large variation in different drop-out rates figures. These variations can be explained by the fact that different research methods and research subjects were used in the selected researchers. The researchers tried to identify the most important factors that impede successful e-learning and that can cause higher drop-out rates. Chang (2004) summarized these factors in three groups: e-learning barriers, unmet student expectations, and faculty time limitation. Major e-learning barriers are: perceived psychological distance (due to spatial and temporal separation among participants) and technological problems. Both barriers can result in low student motivation and feelings of isolation that can of course make students drop out of a course. Next, Chang defines that there are three major student expectations that e-learning courses should meet: timely response time, sufficient supportiveness and comfortable relationship. These expectations often remain unmet due to faculty time limitations. Time limitations are a result of multiple roles that faculty are expected to perform online (these roles are: subject matter expert, online course manager, computer technology consultant) within a limited time span (Chang, 2004).

Mugania (2004) has developed seven categories of e-learning barriers: dispositional, learning style, instructional, organizational, situational, content suitability and techno-logical barriers. She found out that e-learning barriers differ among organizations she researched. Mugania (2004, p. 235) claimed that the technology is only a tool for teaching and learning, which means that the teaching and the learning processes should be reinvented and the roles of the teacher and the learner changed.

It is therefore no surprise that researchers are pointing out that quality e-learning needs efficient and quality student support. As the European agency CEDEFOP (the European Centre for the Development of Vocational Training) concludes in its research E-learning in Europe: How do trainers, teachers and learners rate e-learning? (Aimard \& Mc Cullough, 2006): the emphasis in elearning should shift from the " $\mathrm{e}$ " to the learning itself.

In the context of the renovation of the teaching process and as part of the solution to e-learning quality issues, online tutoring systems are often mentioned. An online tutor is somebody who supports learning processes by means of direct interaction with the learners that are most often separated from each other and from the tutor in time and space (Denis et. al., 2004). The main reason to employ online tutors is to decrease drop-out rates, but also to alleviate student isolation and to comply with a moral obligation to help students complete their studies (Denis et. al., 2004). For these reasons we also decided to implement the tutoring system to support e-learning activities at our faculty.

In this paper we will be presenting the key characteristics of the tutoring system, after which we will be presenting the effects of the introduction of the tutoring system at our faculty. We predicted that our students would positively accept tutors and their support, and that tutors would help students achieve better study results. 


\section{Tutorial Learning Paradigm}

Tutoring is a successful system for traditional learning as Prensky (2002) among others points out. Prensky states that tutorial learning is more efficient than learning in traditional classes because of the personal one-on-one interaction between the tutor and the student. And although tutoring in traditional (physical) environments is still an expensive form of learning, Prensky reminds us that the current technology enables us to connect more students with a single tutor at lower costs and over greater distances. (Prensky, 2002)

A similar opinion is shared by Bork, who emphasizes learning over teaching. In his opinion the currently prevailing information transfer educational paradigm, in which the teacher transfers "knowledge" to often passive students should be changed. In his opinion the future lies in the tutorial learning paradigm, in which learning is seen as an active process in which learners play the leading role. This paradigm will focus on learning in smaller groups with the support of a tutor. The key elements of the tutorial learning paradigm are interactivity, individualization, adaptability, creativity, collaboration etc. (Bork, 2000). Although the learner-centered paradigm is not a new idea, the traditional teacher-centered information transfer paradigm is still mostly in use at our faculties. However, the introduction of the bologna's three cycles study programs should bring a tectonic shift in the methods of teaching and learning that are used in our higher education.

Online tutors support e-learners through different roles. Authors have different classifications of roles tutor perform in e-learning environments. An often cited classification made by Berge defines four basic roles of an online tutor: pedagogical, managerial, social and technical (in McPhearson \& Nunes, 2004). In the pedagogical role tutors support the learning process itself by providing instructions, stimulating questions, examples, feedback, motivation etc. to the learners (Teles et al., 2001). The managerial role requires the tutor to perform basic course administration, track student progress and data etc. (Teles et al., 2001). The tutor's social role includes the efforts to establish a friendly and comfortable environment and a community that stimulates learning, while the technical role requires the tutor to acquaint the students and himself/herself with the ICT that is used for e-learning, and also to provide some technical support to the students (McPhearson \& Nunes, 2004).

To be successful in all the required roles, an online tutor has to possess certain skills and character. Thomas made a 4P checklist according to which a good online tutor should be: positive, proactive, patient and persistent (in Shepherd, 2002). Many authors emphasize the need for tutors to be experts in the field they are tutoring (Shepherd, 2002). Tutors should also have highly developed online communication skills, be ICT literate and familiar with the e-learning technology and have a positive attitude toward students and learning (Shepherd, 2002).

And finally, tutors should also participate in training programs, which help them to develop their skills, learn about the roles they have as online tutors and also learn about the characteristics of elearning that make it different from traditional, face-to-face learning. Proper training seems to be an important factor for the successful delivery of e-learning courses (Smith, 2005) and in our Internet research of publicly available training programs for online tutors we found out that training programs put great emphasis on the practical aspects of tutoring, during which tutors practice online communication in online learning environments with other to-be tutors (Sulčič \& Sulčič, 2007). The training programs are important because tutors get to experience what it is like to be an online student and most importantly, they also receive valuable feedback about how well they perform in different tutoring roles directly from other participants of the training program. This feedback can help tutors develop their tutoring skills and perform better in tutoring situations with real students (Sulčič \& Sulčič, 2007). 


\section{Tutoring System in Practice - A Research}

To provide better support for learners that participate in the online E-business course at our faculty, we decided to implement the online tutoring system. The E-business course is an elective course that is almost entirely delivered online. To supplement the online delivery, at least two face-to-face meetings with the students are usually organized during the course (depending on student characteristics and demand). In the study years 2004/2005 and 2005/2006 we had over 100 students enrolled in the E-business course, so we decided that students could get better learning support if we divided them in groups of approximately 20-40 students and assign an online tutor to each group. Former students that already completed the course were invited to become online tutors.

The tutoring system was also introduced for the Business informatics course. The Business informatics course is a compulsory course for students of the second year. In addition to online activities, half of the course took place in traditional classrooms. In the academic year 2005/2006 125 students took the course and were divided in four groups. Each group was tutored by a teaching assistant (two groups for one assistant). The teaching assistants also participated during faceto-face traditional lectures, which were part of the course.

The characteristics of tutor supported courses that were included in our research are presented in Table 2.

Table 2: Courses at our faculty that were supported by online tutors

\begin{tabular}{lccc}
\hline Course & Duration & Type & Number of students \\
\hline E-business & March - May 2005 & Elective & 105 \\
E-business & March - May 2006 & Elective & 109 \\
Business informatics & October 2005 - January 2006 & Compulsory & 125 \\
\hline
\end{tabular}

As well trained tutors can greatly improve the quality of e-learning (Smith 2005), we provided internal training for our to-be online tutors before they started working with the students. The first training program was held in January 2005. During this program our tutors became familiar with our online learning environment and developed appropriate online communication skills that enabled them to interact efficiently with the students. The online learning environment that is used at our faculty is based on Moodle (http://www.moodle.org/), an open source learning management system. We use our Moodle based learning environment (called e-classroom) for threaded forum discussions and to support learning activities (study material delivery, assignments management, grading).

The role of our online tutors in the E-business and Business informatics course was to monitor student activity and progress, provide technical, professional and learning support to the students, motivate students for work and discussions, moderate discussions and also interact with the teacher of the course by reporting student progress. In a few cases tutors also assisted the teacher of the course at grading, though the teacher did most of the grading on his/her own.

To evaluate the impact tutors had on students we performed an activity analysis of student and tutor posting and performed several surveys among students after the completion of the tutor supported courses. The data was statistically analyzed and will be presented using descriptive statistics, correlation analysis and linear regression analysis. In the following sections we will be presenting the most interesting findings. 


\section{Activity Analysis}

We analyzed the number of posts that were posted by students and their tutors on discussion forums, which was the main study activity for the E-business course. As the number of posts varied week by week due to different difficulty levels of assignments, we decided to calculate the average number of student posts per week and the average number of tutor posts per week. To avoid differences in group size, we divided these numbers by the number of students in each group, so our final analysis included the average number of student posts per week per student for each group and the average number of tutor posts per week per student for each group. Also, the average grade that students assigned to their tutors on a weekly basis was included in the analysis.

The correlation analysis showed some statistically significant differences between observed variables as presented in Table 3. Only two correlations are statistically significant. There is a positive correlation between average student activity and average tutor activity, and a positive correlation between tutor's grade (given by the students) and average tutor activity.

\section{Table 3: Activity analysis correlation table}

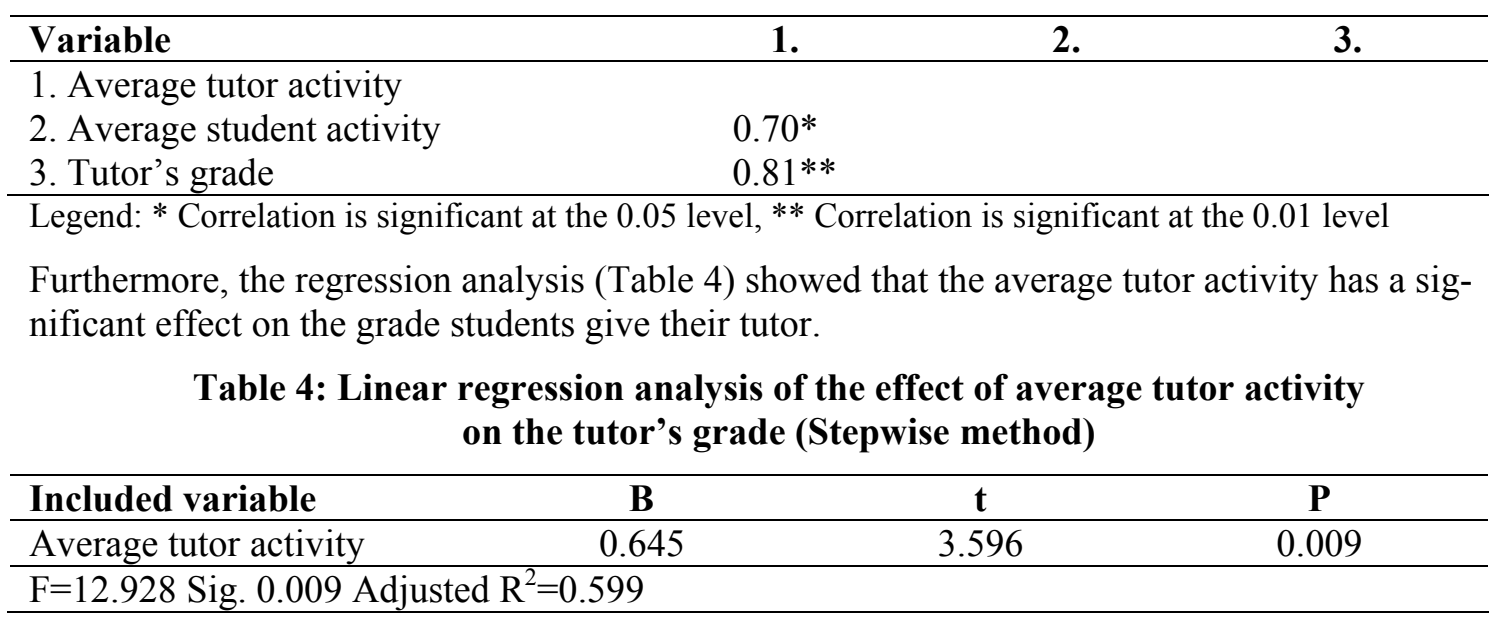

The impact of tutor activity on tutor's grade is statistically significant $(\mathrm{P}=0.009)$ and explains $59.9 \%\left(\mathrm{R}^{2}\right)$ of variability in the tutor's grade. In other words, for each 1 unit increase in average tutor posting, the students would give their tutor a 0.645 higher grade.

A smaller statistically significant difference can also be observed between the average tutor activity and the average student activity, as seen in Table 5.

Table 5: Linear regression analysis of the effect of average tutor activity on the average student activity (Stepwise method)

\begin{tabular}{lccc}
\hline \multicolumn{1}{c}{ Included variable } & B & t & P \\
\hline Average tutor activity & 2.747 & 2.557 & 0.038 \\
\hline $\mathrm{F}=6.540$ Sig. 0.038 Adjusted $\mathrm{R}^{2}=0.409$ & & \\
\hline
\end{tabular}

These results mean that the quantity of tutor posts had more effect on how students graded their tutors than on the quantity of student posts. However, the tutor activity also had a significant positive effect on student activity. 


\section{Survey Analysis}

As already mentioned, we performed different surveys among our students after the completion of the tutor supported courses. In the surveys we tried to research the tutor's role in the eclassroom (the online learning environment). The surveys that were performed are presented in Table 6.

Table 6: Surveys performed among students about tutor support

\begin{tabular}{lcc}
\hline Course & Survey duration & \% of respondents \\
\hline E-business (EC - PT) - 2004/2005 & 22.5 .2006 & $80.0 \%$ \\
E-business (EC - PT/FT) - 2005/2006 & $21 .-28.5 .2006$ & $91.7 \%$ \\
Business Informatics (CC - FT) - 2005/2006 & $11 .-18.1 .2006$ & $72.0 \%$ \\
\hline
\end{tabular}

Legend: EC - elective course, CC - compulsory course, PT - part-time students, FT - full-time students

Some data were also collected on a weekly basis. Each week students were asked to assess their tutor's work during the week. The comparison among students is presented in Table 7.

Table 7: The tutor's role in the e-classroom

\begin{tabular}{|c|c|c|c|c|c|}
\hline \multirow[t]{2}{*}{ Variables } & \multicolumn{2}{|c|}{$\begin{array}{l}\text { Elective course } \\
\text { (EC) }\end{array}$} & \multirow{2}{*}{$\begin{array}{c}\text { Compulsory } \\
\text { course (CC) } \\
\text { FT } \\
\end{array}$} & \multirow{2}{*}{$\begin{array}{l}\text { PT : FT } \\
\text { t-test - P }\end{array}$} & \multirow{2}{*}{$\begin{array}{l}\text { EC : CC } \\
\text { t-test }-P\end{array}$} \\
\hline & FT & PT & & & \\
\hline A tutor can replace the teacher. & 3.6 & 4.0 & 3.9 & & \\
\hline Assessment of tutor's support. & 3.6 & 4.5 & 3.8 & 0.00 & 0.00 \\
\hline $\begin{array}{l}\text { A tutor can improve study suc- } \\
\text { cess. }\end{array}$ & 4.0 & 4.6 & 3.7 & 0.00 & 0.00 \\
\hline $\begin{array}{l}\text { The teacher was easily acces- } \\
\text { sible. }\end{array}$ & 3.8 & 4.6 & 3.8 & 0.00 & 0.00 \\
\hline
\end{tabular}

Legend: Students assessed variables on a scale from 1 (strongly disagree) to 5 (strongly agree); PT - parttime students, FT - full-time students

The tutor's role was more valued by part-time students than by full-time students. We can connect this with the different characteristics of both study forms. In our institution, part-time students usually have fewer lectures than full-time students and consequently part-time students have less contact with their teachers than full-time students do. For this reason it is not surprising that part-time students were more acceptant of the tutor support that was provided in the eclassroom. Part-time students also thought the tutor/teacher in the e-classroom was easily accessible (4.6) and that a tutor can greatly improve their study success (4.6). The differences between part-time and full-time students and between students of the elective and the compulsory course were statistically significant (Table $7, \mathrm{P}<0.05$ ).

The correlations between the variables that describe the tutor's role and the students' perception about gained knowledge and the student's final course grade were also analyzed. The results are presented in Table 8, in which only statistically significant correlations are shown.

Table 8: Tutor's role correlation table

\begin{tabular}{lcccc}
\hline \multicolumn{1}{c}{ Variables } & $\mathbf{1 .}$ & $\mathbf{2 .}$ & $\mathbf{3 .}$ & $\mathbf{4 .}$ \\
\hline $\begin{array}{l}\text { 1. A tutor can replace the teacher. } \\
\text { 2. Assessment of tutor's support. }\end{array}$ & $0.47^{* *}$ & & & \\
3. A tutor can improve study success. & $0.49^{* *}$ & $0.34^{* *}$ & & \\
$\begin{array}{l}\text { 4. The teacher was easily accessible. } \\
\text { 5. Student's course grade. }\end{array}$ & $0.54^{* *}$ & $0.45^{* *}$ & $0.43^{* *}$ & \\
6. Gained knowledge & $0.37^{* *}$ & $0.41^{* *}$ & $0.42^{* *}$ & $0.41^{* *}$ \\
\hline Legend: * Correlation is significant at the 0.05 level, ${ }^{* *}$ Correlation is significant at the 0.01 level
\end{tabular}


As can be seen from Table 8, there are positive correlations between the opinion about the tutor's role and the perception of gained knowledge. The more students agreed with the statement that a tutor can replace the teacher, the better they assessed the tutor's support in the e-classroom; and the more they thought that a tutor can improve their study success, the greater their perception of received knowledge was (as compared to traditional lectures). However, no significant correlations with the students' final course grade were noticed.

We also tested the effects of different variables that define the tutor's role on the perception of gained knowledge with a linear regression analysis. The results of the analysis are presented in Table 9.

Table 9: Linear regression analysis of the effects of tutor support on the perception of gained knowledge (Stepwise method)

\begin{tabular}{lccc}
\hline \multicolumn{1}{c}{ Included variables } & B & t & P \\
\hline A tutor can improve study success. & 0.268 & 3.437 & 0.001 \\
Assessment of tutor's support. & 0.290 & 3.114 & 0.002 \\
The teacher was easily accessible. & 0.199 & 2.572 & 0.011 \\
\hline F=22.476 Sig. 0.000 Adjusted $\mathrm{R}^{2}=0.280$ & & &
\end{tabular}

$28 \%$ of the variation $\left(\mathrm{R}^{2}\right)$ in the perception of gained knowledge can be explained with the opinion on whether a tutor can improve study success, the assessment of tutor's support and the opinion on whether the students thought the teacher was easily accessible in the e-classroom.

We also wanted to analyze the effect of different group sizes on study outcomes, as the group sizes of the elective course E-business were quite different (ranging from 12 to 42 students). Table 10 shows the results of the linear regression analysis that was performed.

Table 10: Linear regression analysis of the effect of group size on the student's course grade (Stepwise method)

\begin{tabular}{lccc}
\hline \multicolumn{1}{c}{ Included variable } & B & t & P \\
\hline Group size & -0.039 & -3.078 & 0.003 \\
\hline $\mathrm{F}=9.472$ Sig. 0.003 Adjusted $\mathrm{R}^{2}=0.080$ & & & \\
\hline
\end{tabular}

We found out that only $8 \%$ of variation of students' final course grade can be explained by different group size, but the impact is still statistically significant. Students from bigger groups were less successful than students from smaller groups. The results from Table 10 showed that if the group size was increased by 1 unit ( 1 additional student), the average grade of the group would decrease by 0,039 points $(\mathrm{B}=-0.039)$.

In a survey that was performed among the students of the academic year 2005/2006 after the completion of the E-business course, students were also asked some specific questions about their online tutors. 104 students of 109 responded to our survey. Among other questions, we asked our students about how often should the online tutor be active in the e-classroom and half of the students $(53 \%)$ responded that tutors should be active more times a day. $26 \%$ of the students thought the tutors are needed only once a day, and the remaining students $(21 \%)$ thought they were needed only several times a week. These results show that a good half of our students needs tutors to be present more times a day.

\section{A Model for Online Tutors}

Basing on our research (both the activity and survey analysis) and our experience with online tutoring, we suggest a model for online tutors, which is shown in Figure 1. Our model tries to iden- 
tify the most important elements of online tutoring that should be closely monitored and developed. We believe it can provide a general guideline for tutors and institutions interested in providing better support for their e-learning courses.

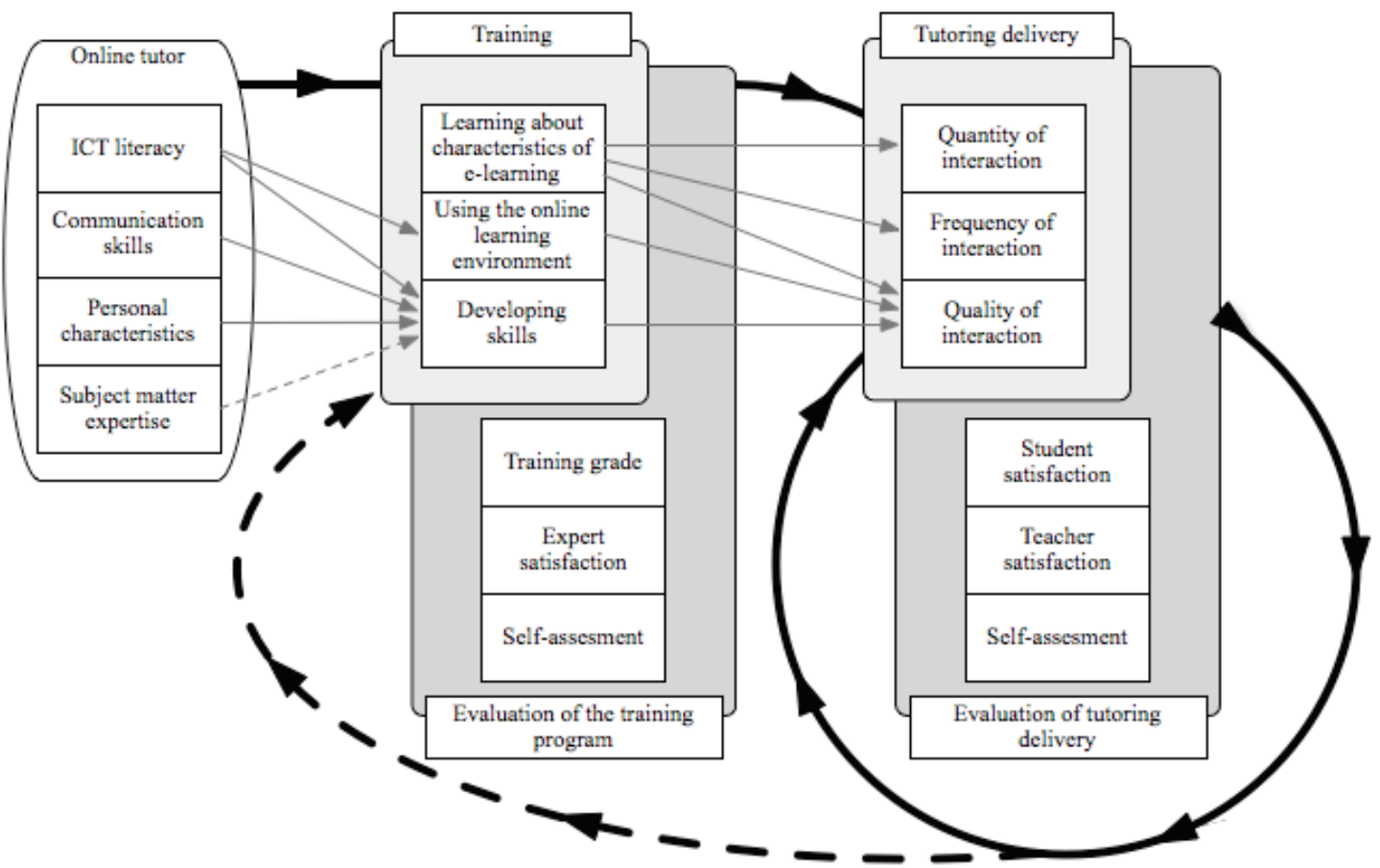

Figure 1: Online tutoring model

As can be seen from Figure 1, online tutors enter their tutoring experience with some already developed skills. In our opinion (basing on literature review) the most important skills for an online tutor are:

- ICT literacy,

- Communication skills,

- Personal characteristics,

- Subject matter expertise.

A person, whose defined skills are already on a certain level, can enter a training program for online tutors (Figure 1) in which his/her skills will be further developed. During the training all tutor's skills will be developed - though the tutor's subject matter expertise will not be dealt with so intensively. However, subject matter expertise will still play an important role in the tutoring delivery. The training program also helps the tutor to understand the specifics of e-learning and to get familiar with the online learning environment. For the latest the tutor will need to employ existing ICT literacy skills. The training program is evaluated on different levels (Figure 1): each tutor performs a self-assessment that is based on the interaction with other participants; he/she receives an official final grade after the completion of the training program and receives a certain level of satisfaction from the expert/leader of the training program.

If the evaluation gives positive results, the online tutor is ready to move to the tutoring delivery (Figure 1) process in which the tutor's work is judged (evaluated) on the basis of quantity, frequency and quality of his/her interaction with other participants of the e-learning delivery process. The quantity depends on the number of posts, the frequency describes how often the tutor actively participates in the online learning environment, while the quality of a tutor's interaction 
is defined by his/her skills. The quantity, frequency and quality of interaction must meet participants' expectations. A tutor that has learnt about the characteristics of e-learning during the training program should be able to know how often, how much and how will he/she interact with other participants of e-learning. The evaluation of his /her work in the tutoring delivery process will be based on the level of satisfaction from students and the teacher of the course and also on the selfassessment each tutor should perform during and after the tutoring delivery process. Should the tutor receive positive results from all of the three evaluation criteria, he/she can enter a new tutoring delivery process; in the opposite case the tutor should consider entering another training program to further develop his/her skills.

\section{Conclusion}

Our research confirmed the predictions made at the beginning of the paper. Online tutors do play an important role in supporting e-learning delivery and can perhaps help to improving the alarming drop-out figures e-learning course have been showing in the past years. Online tutors help to fulfill student expectations that can cause students to drop-out if they remain unmet. This is especially important for part-time students that apparently don't get sufficient support from traditional learning. Because of the importance of the role of online tutors, it is necessary to choose individuals with a set of existing skills that can be developed through careful prepared training programs. Only well-trained tutors will be able to satisfy student expectation about the quantity, frequency and quality of learning supporting activities. We combined these findings in a general model for online tutoring that tries to identify the key elements of quality tutoring support for elearning. The research showed that well educated tutors with appropriately developed skills were able to improve the quality of e-learning informatics-related courses at a higher educational level business school. In order to test our finding and our online tutoring model we think that further researches on the impacts of the tutoring system for e-learning should be performed in schools of different orientation and level, and on different course subjects as well.

\section{References}

Aimard, V. \& Mc Cullough, C. (2006). E-Learning in Europe: How do trainers, teachers and learners rate e-learning? Retrieved 20. 4. 2006 from:

http://cms.eun.org/shared/data/pdf/report_survey_teachers_and_learners_and_e-learning_final.pdf

Bork, A. (2000). Teaching and learning are often mentioned together. Retrieved 2. 11. 2006 from: http://www.educause.edu/ir/library/pdf/ERM0010.pdf

Chang, S. (2004). The roles of mentors in electronic learning environments. AACE Journal, 12(3), 331342.

Dagger, D. \& Wade, V. P. (2004). Evaluation of Adaptive Course Construction Toolkit (ACCT). Retrieved 31. 8. 2006 from: http://wwwis.win.tue.nl/ acristea/AAAEH05/papers/6a3eh_daggerd_IOS format_v1.1.pdf

Denis, B., Watland, P., Pirotte, S. \& Verday, N. (2004). Roles and competencies of the e-tutor. Retrieved 21. 4. 2006 from: http://www.shef.ac.uk/nlc2004/Proceedings/Symposia/Symposium6/Denis et al.htm

Diaz, D. P. (2002). Online drop rates revisited. The Technology Source Archives. May/June 2002. Retrieved 31. 8. 2006 from: http://technologysource.org/article/online_drop_rates_revisited/

Flood, J. (2002). Read all about it: Online learning facing $80 \%$ attrition rates. VTOJDE, 3(2). Retrieved 31. 8. 2006 from: http://tojde.anadolu.edu.tr/tojde6/articles/jim2.htm

Holmberg, B. (1995). The evolution of the character and practice of distance education. Open Learning, 10(2), 47-53.

MacDonald, C. J., Stodel, E. J., Farres, L. G., \& Breithaupt, K. (2001). In M. A. Gabriel, The demand driven learning model: A framework for Web-based learning. The Internet and Higher Education, 1(4), 9-30. 
Masie Center - eLearning Consortium. (2003). Departure, abandonment, and drop-out of e-learning: Dilemma and solutions. Final report. Retreived 30. 8. 2006 from: http://www.masie.com/researchgrants/2003/JMU Final Report.pdf\#search=\%22dropout $\% 20 \mathrm{e}-$ learning $\% 22$

McPherson, M. \& Nunes, M. B. (2004). The role of tutors as an integral part of online learning support. Retrieved 16. 4. 2006 from: http://www.eurodl.org/materials/contrib/2004/Maggie_MsP.html

Mungania, P. (2004). Employees' perceptions of barriers in e-learning: The relationship among barriers, demographics, and e-learning self-efficacy - a Dissertation. University of Lousville.

Prensky, M. (2002). E-Nough! Retrieved 2. 11. 2006 from: http://www.marcprensky.com/writing/Prensky\%20-\%20e-Nough\%20-\%20OTH\%20111\%20March\%202003.pdf

Shepherd, C. (2002). In search of the perfect e-tutor. Retrieved 19. 4. 2006 from: http://www.fastrakconsulting.co.uk/tactix/Features/perfect etutor.htm

Smith, T. C. (2005). Fifty-one competencies for online instruction. Retrieved 31. 8.2006 from: http://www.thejeo.com/Ted\%20Smith\%20Final.pdf\#search=\%22fiftyone $\% 20$ competencies $\% 20$ online $\% 20$ instruction $\% 20$ smith $\% 22$

Sulčič, V. \& Sulčič, A. (2007). Usposabljanje učiteljev in mentorjev za e-izobraževanje (UUMeI) - Poročilo o izvedbi razvojnega projekt FM. Koper: UP Fakulteta za managenet, Center za e-izobraževanje FM.

Teles, L., Ashton, S., Roberts, T. \& Tzoneva, I. (2001). The role of the instructor in e-learning collaborative environments. Retrieved 16. 4. 2006 from: http://www.telestraininglobal.com/press/media/techknowlo.article.pdf

Tyler-Smith, K. (2006). Early attrition among first time elearners: A review of factors that contribute to drop-out, withdrawal and non-completion rates of adult learners undertaking elearning programmes. $V$ Journal of Online Learning and Teaching, 2(2). Retrieved 30. 8. 2006 from: http://jolt.merlot.org/Vol2 No2 TylerSmith.htm

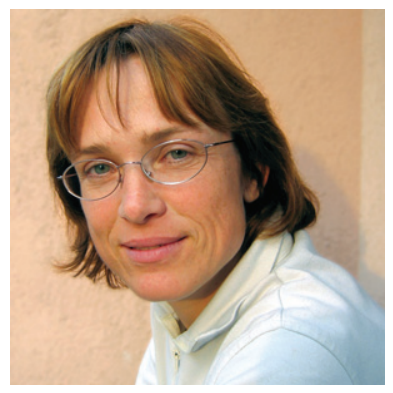

\section{Biographies}

Viktorija Sulčič participates in different courses of business informatics at the Faculty of Management Koper and leads the faculty's Center for e-learning. Her research work is closely connected to e-learning. In her doctoral research, which is almost finished, she established the model of effective e-learning suitable for small learning environments.

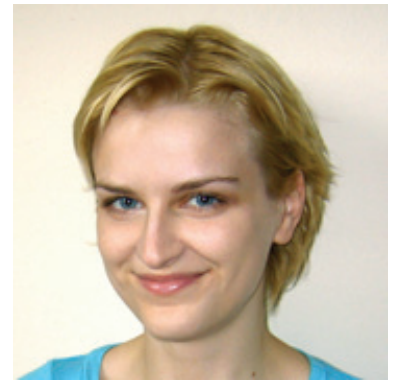

As a student of media communications Alja Sulčič became interested in the characteristics of computer-mediated communication and the possibilities of creating social networks and new forms of human interactions on the Internet. This interest led her to the Center for elearning at the Faculty of managements Koper, where she now researches the educational possibilities of existing and emerging ICT. She is also an online tutor for the E-business course at the faculty and an advocate of user-friendly and open learning environments. More about her research interests and personal experiences can be found on

her blog at: http://ialja.blogspot.com. 